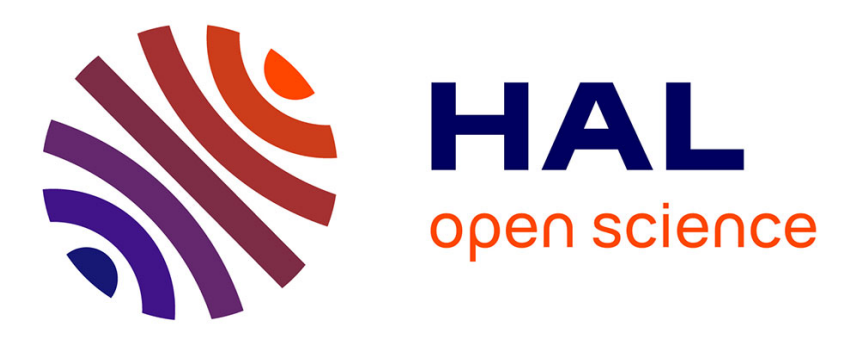

\title{
Induction Heating Technology and Its Applications: Past Developments, Current Technology, and Future Challenges
}

\author{
Oscar Lucia, Pascal Maussion, Enrique J. Dede, Jose Burdio
}

\section{- To cite this version:}

Oscar Lucia, Pascal Maussion, Enrique J. Dede, Jose Burdio. Induction Heating Technology and Its Applications: Past Developments, Current Technology, and Future Challenges. IEEE Transactions on Industrial Electronics, 2013, vol. 61 (n5), pp. 2509-2520. 10.1109/TIE.2013.2281162 . hal01107267v2

\section{HAL Id: hal-01107267 \\ https://hal.science/hal-01107267v2}

Submitted on 23 Jan 2015

HAL is a multi-disciplinary open access archive for the deposit and dissemination of scientific research documents, whether they are published or not. The documents may come from teaching and research institutions in France or abroad, or from public or private research centers.
L'archive ouverte pluridisciplinaire HAL, est destinée au dépôt et à la diffusion de documents scientifiques de niveau recherche, publiés ou non, émanant des établissements d'enseignement et de recherche français ou étrangers, des laboratoires publics ou privés. 


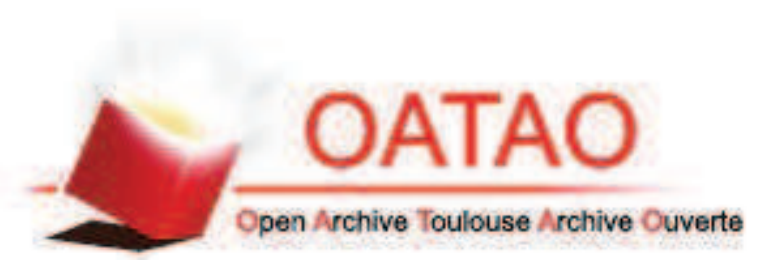

\section{Open Archive TOULOUSE Archive Ouverte (OATAO)}

OATAO is an open access repository that collects the work of Toulouse researchers and makes it freely available over the web where possible.

This is an author-deposited version published in : http://oatao.univ-toulouse.fr/ Eprints ID : 12156

To link to this article : DOI: $10.1109 /$ TIE.2013.2281162

http://dx.doi.org/10.1109/TIE.2013.2281162

To cite this version Lucia, Oscar and Maussion, Pascal and Dede, Enrique and Burdio, Jose M. Induction Heating Technology and Its Applications: Past Developments, Current Technology, and Future Challenges. (2013) IEEE Transactions on Industrial Electronics, vol. 61 (n5). pp. 2509-2520.

Any correspondance concerning this service should be sent to the repository administrator: staff-oatao@,listes-diff.inp-toulouse.fr 


\title{
Induction Heating Technology and its Applications: Past Developments, Current Technology, and Future Challenges
}

\author{
O. Lucía, Member, IEEE, P. Maussion, Member, IEEE, E. Dede, Member, IEEE, and J. M. Burdío, Senior Member, IEEE.
}

\begin{abstract}
Induction heating technology is nowadays the heating technology of choice in many industrial, domestic, and medical applications due to its advantages regarding efficiency, fast heating, safety, cleanness, and accurate control. Advances in key technologies, i.e. power electronics, control techniques, and magnetic component design, have allowed the development of highly reliable and cost-effective systems, making this technology readily available and ubiquitous.

This paper reviews induction heating technology summarizing the main milestones in its development, and analyzing the current state-of-art of induction heating systems in industrial, domestic and medical applications, paying special attention to the key enabling technologies involved. Finally, an overview of future research trends and challenges is given, highlighting the promising future of induction heating technology.
\end{abstract}

Index terms - Induction heating, resonant power conversion, electromagnetic analysis.

\section{INTRODUCTION}

Induction heating $(\mathrm{IH})$ provides contactless, fast, and efficient heating of conductive materials. It is becoming one of the preferred heating technologies in industrial [1], domestic [2], and medical applications [3], among other applications, due to its advantages when compared with other classical heating techniques such as flame heating, resistance heating or traditional ovens or furnaces.

Fig. 1 shows a typical arrangement of an induction heating system [4-7] in a longitudinal flux configuration. An ac source is used to supply an alternating voltage to an induction heating coil. The coil generates an alternating magnetic field, in which the induction target, i.e. the load, is immersed. As a consequence, the induction target is heated by means of two physical phenomena: eddy currents and magnetic hysteresis [4]. Eddy currents oppose to the magnetic field applied to the induction target, and they produce the heating by Joule effect. This is commonly the main heat source in IH processes. In addition to this, magnetic hysteresis creates additional heating in ferromagnetic materials. The typical operating frequencies of these systems ranges from line frequency, e.g. industrial and high power applications, up to a few MHz's, typical of medical systems.

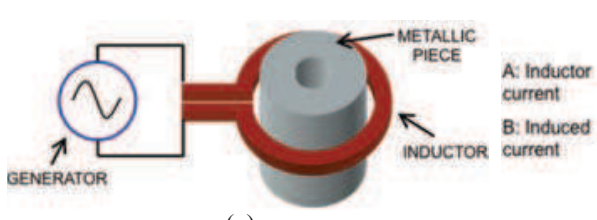

(a)

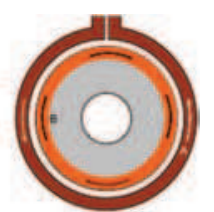

(b)

Fig. 1. Typical arrangement of an induction heating system in a longitudinal flux configuration: (a) general view and (b) top view.

Among the advantages of $\mathrm{IH}$, the following ones are commonly recognized:

- Fast heating: IH technology directly heats the induction target, reducing wasted heat and significantly reducing heating times thanks to high power densities and without any thermal inertia.

- Efficiency: Modern efficient designs of the coil and the power converter allows obtaining efficiency values higher than $90 \%$, significantly improving conventional heating techniques. Moreover, since only the induction target is heated, the heat loss through the ambient and surrounding elements is minimized and high temperatures can be reached.

- Controlled heating: The power applied by the IH system and the location can be accurately controlled through the appropriate design of the coil and the power converter and its control. As a consequence, advanced features can be implemented such as local heating, predefined temperature profiles, etc.

- Improved industrial process: IH consistency and repeatability improves the quality process and maximizes the productivity of the process. Moreover, since IH is a contactless heating process, the induction target is not affected by the heating tool, i.e. the coil, and the quality is ensured.

- Cleanness and safety: Since IH heats directly the induction target, the temperature of the surroundings of the heating area is lower, avoiding burning other materials, such as spilled food in the case of domestic IH. Moreover, there is no local pollution unlike fossil fuel furnaces.

These advantages, and the progress in $\mathrm{IH}$ technology achieved in recent years, have boosted applications of IH that can be classified into industrial, domestic, and medical applications. The main enabling technologies that have allowed this progress are power electronics, modulation and control algorithms, and magnetic component design. Table I 
TABLE I. DIFFERENTIAL CHARACTERISTICS OF INDUCTION HEATING APPLICATIONS FOR EACH ENABLING TECHNOLOGY.

\begin{tabular}{|c|c|c|c|}
\hline Enabling tec & Power Electronics & $\begin{array}{c}\text { Modulation and Control } \\
\text { Algorithms }\end{array}$ & Magnetic Components \\
\hline Industrial & $\begin{array}{l}\text { - High power. } \\
\text { - Improved reliability. } \\
\text { - Assembly-line read. } \\
\text { - Low-high operating } \\
\text { frequency. }\end{array}$ & $\begin{array}{l}\text { - Multi-zone control algorithm. } \\
\text { - Improved interface and } \\
\text { communications. } \\
\text { - Variable load and power ranges. } \\
\text { - Multi-load management. } \\
\text { - Temperature control. }\end{array}$ & $\begin{array}{l}\text { - High efficiency. } \\
\text { - Variable shape. } \\
\text { - Optimized heat } \\
\text { distribution. }\end{array}$ \\
\hline Domestic & $\begin{array}{l}\text { - Low cost. } \\
\text { - High efficiency. } \\
\text { - Limited cooling } \\
\text { capability. } \\
\text { - Medium operating } \\
\text { frequency. }\end{array}$ & $\begin{array}{l}\text { - Power factor and harmonics control. } \\
\text { - Variable load and power ranges. } \\
\text { - Need to avoid accoustic noise. } \\
\text { - Multi-load management. } \\
\text { - Temperature control. }\end{array}$ & $\begin{array}{l}\text { - High efficiency. } \\
\text { - Heat non-ferromagnetic } \\
\text { materials. } \\
\text { - Flexible cooking surfaces. }\end{array}$ \\
\hline Medical & $\begin{array}{l}\text { - Low power. } \\
\text { - High quality factor } \\
\text { resonant tank. } \\
\text { - High operating } \\
\text { frequency. }\end{array}$ & $\begin{array}{l}\text { - Accurate power and temperature } \\
\text { control. } \\
\text { - Frequency selection. }\end{array}$ & $\begin{array}{l}\text { - Local heating. } \\
\text { - Controlled magnetic field } \\
\text { interactions. } \\
\text { - Ferromagnetic fluids. }\end{array}$ \\
\hline
\end{tabular}

summarizes the main differential characteristics of the main IH applications and the enabling technologies involved.

Although all IH applications share the main fundamental principle, they have differential characteristics that have to be addressed through the technologies involved in each design. Industrial applications require usually higher output powers and higher reliability, constraining the power converter topology selection. Besides, since they have intensive industrial usage, assembly-line readiness and an improved interface and communications are required. In addition to this, the inductor design needs to adapt to the different shapes of induction targets, e.g. shafts, gears, etc., and provide the required heat profile.

By contrast, domestic IH systems that are usually implemented in induction cookers require low cost and highly efficient implementations due to the limited cooling capabilities. Besides, the wide load range due to the different materials, geometries and required output powers is the main challenge from the control point of view. The inductor system must be designed also to obtain high-efficiency and be able to heat non-ferromagnetic materials typical of some cultures. Finally, medical applications require specific but vital requirements to $\mathrm{IH}$ systems. These systems are usually low power, but they require very accurate control of the heating process, including temperature and localization.

The next lines give a brief outline of the evolution of $\mathrm{IH}$ systems and its applications.

\section{HISTORY OF INDUCTION HEATING SYSTEMS}

$\mathrm{IH}$ technology has been in constant evolution following industrial and technological advances since the end of XIX century [8]. The principle of induction heating was discovered by Michael Faraday when he discovered induced currents by a magnet. James C. Maxwell developed later the unified theory of electromagnetism and James P. Joule described the heat produced by a current in a conductor, establishing the fundamental principles of induction heating.

The first industrial applications of the IH phenomenon were identified in 1887 by Sebastian Z. de Ferranti, who proposed $\mathrm{IH}$ for melting metals, filling the first patent on industrial applications of IH. Later, in 1891, F.A. Kjellin presented the first fully functional induction furnace. The first major advance came when Edwin F. Northrup implemented the first high-frequency induction furnace at Princeton in 1916. Nearly at the same time, M.G. Ribaud developed highfrequency IH technology using spark-gap generators and, later, Valentin P. Vologdin developed IH generators using machine generators and vacuum tubes. These were the beginnings of modern high-frequency induction heating systems. During WWII and later, automotive and aircraft industry boosted the use of IH technology not only for melting metals but also for advanced material treatment, significantly increasing the IH technology penetration on industrial processes. The second major revolution of IH technology came along with the development of solid-state generators. These generators took advantage of new power semiconductor technology, mainly thyristors, to implement highly reliable power converters. Later, the development of higher frequency power devices, such as the power bipolar junction transistor (BJT) and the power metal-oxide-semiconductor field-effect transistor (MOSFET), enabled the design of higher efficiency power converters, making IH the technology of choice in many applications. The grade of performance and efficiency achieved in IH systems, together with further advances in semiconductor technology and the introduction of the successful insulated-gate bipolar transistor (IGBT), expanded the applications of IH technology beyond the industrial environment. Since late 80 s, many domestic applications of 


\begin{tabular}{c|ccc}
\hline Enabling technology & Power Electronics & $\begin{array}{c}\text { Modulation and Control } \\
\text { Algorithms }\end{array}$ & Magnetic Components \\
Application & {$[1],[4],[5],[9-27]$.} & {$[25],[26],[28-33]$.} & {$[26],[30],[34-43]$.} \\
Industrial & {$[2],[44-63]$.} & $\begin{array}{c}\text { [33], [50], [62], [64-78]. } \\
\text { Industrial and domestic } \\
\text { techniques applied. }\end{array}$ & $\begin{array}{c}\text { [42], [43], [45], [62], [77], [79- } \\
\text { Domestic }\end{array}$ \\
Medical & {$[3],[90-92]$.} & {$[43],[93-99]$.} \\
\hline \hline
\end{tabular}

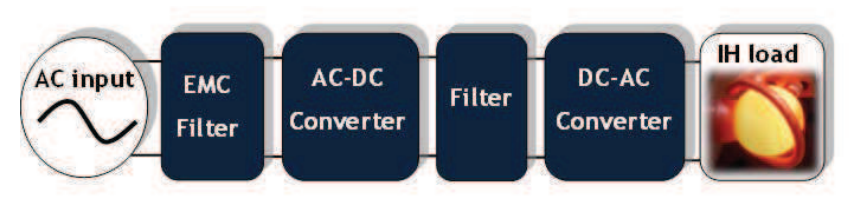

Fig. 2. Typical power conversion flow in an IH system.

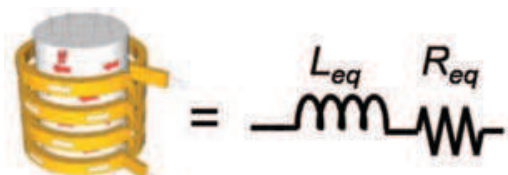

(a)

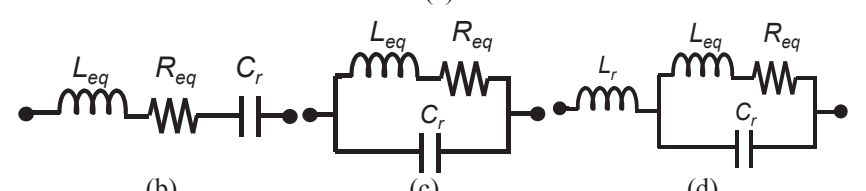

(b)

(c)

(d)

Fig. 3. Electrical equivalent model of an IH load (a) and basic resonant configurations: (b) series, (c) parallel, and (d) hybrid series-parallel.

IH have appeared, and nowadays induction heating cookers are well-established in many countries. Moreover, since late 80 s and, specially, in the XXI century, a special interest of IH for medical applications has appeared due to its advantages in terms of precise and local heating for hyperthermia treatment.

Currently, IH technology is evolving fast towards highly reliable and efficient systems, allowing implementing highly versatile systems that makes $\mathrm{IH}$ ubiquitous. Next section summarizes the state-of-art of the enabling technologies that makes possible such systems.

\section{ENABLING TECHNOLOGIES}

Advances in key technologies have made possible the development of IH technology [17]. This section summarizes the current state-of-art of the main enabling technologies commonly involved in IH systems: power electronics, modulation and control algorithms, and magnetic component design. A selection of references summarizing the state-of-art is given in next subsections, and they are also summarized in Table II according to the application that they focus on.

\section{A. Power electronics}

Fig. 2 shows the main power conversion scheme present in most of the single coil IH systems. Firstly, an electromagnetic compatibility (EMC) filter ensures that the power converter complies with the electromagnetic standards. After that, an ac-dc converter provides a dc-bus to supply the inverter block. The rectifier stage can be either a noncontrolled stage, i.e. diode rectifier, or a controlled one. The latter implementation is used to provide an additional degree of freedom for the control system, and can be implemented either as a controlled rectifier [12] or as a diode rectifier plus a dc-dc converter [25]. Depending on the applications, some IH systems also include a power factor corrector block in order to increase voltage and ensure sinusoidal input current [73].

The dc-ac power converter, also known as inverter, is the most important one and has to supply medium frequency currents to supply the inductor [18]. The operating frequency is usually higher than $20 \mathrm{kHz}$ in order to avoid audible noise and rises up to $1 \mathrm{MHz}$ depending on the application. Currently, most IH systems feature either voltage source or current source resonant inverters [23] in order to obtain efficient and high-power-density implementations. The induction heating load is usually modeled as an equivalent resistor $R_{e q}$ and inductor $L_{e q}$ (Fig. 3 (a)), which may be connected in series or parallel, depending on the model, and additional external inductors and/or capacitors are added to complete the resonant tank. The resonant inverter topology used can be classified either considering the type or resonance used or the number of switching devices.

Considering the resonant tank, the most used configurations are the second-order series resonant (Fig. 3 (b)) and parallel resonant circuits (Fig. 3 (c)), and the third-order LLC series-parallel resonant circuit (Fig. 3 (d)). The series resonant RLC circuit [9], [50] is commonly used in voltage source inverters and ensures zero mean current through the inductor, due to the series capacitor, and zero voltage switching (ZVS) conditions above the resonant frequency, i.e. zero voltage across the device during the switching process that ideally leads to zero switching losses. By contrast, the parallel-resonant RLC circuit [24] is used in current source inverters, achieving reduced current through the switching devices and zero current switching (ZCS), i.e. switching with zero current through the device that leads to ideally zero switching losses. For this reason, this topology is chosen when high inductor current is demanded in order to reduce stress in the power devices. Finally, the series-parallel LLC circuits combines the benefits of parallel resonance with additional load short-circuit protection [10], [13], making it one of the most used topologies for high power industrial applications. 
All these three resonant configurations can also include a transformer to provide isolation and additional voltage gain [10].

According to the number of switching devices, the inverter topologies commonly used in IH are the full-bridge [21], halfbridge [19], [20], and single-switch [63] resonant inverters. Fig. 4 shows the voltage source full and half-bridge in the series resonant form, and a ZVS single-switch inverter. The full-bridge topology is commonly used for output powers higher than $5 \mathrm{~kW}$, and it is the standard choice for industrial systems. By contrast, the half-bridge topology is the preferred one for domestic induction systems up to $5 \mathrm{~kW}$, whereas the single-switch inverter is used in small IH generators and domestic systems up to $2 \mathrm{~kW}$.

Apart from the single output topologies previously detailed, modern designs include multiple-coil systems intended to improve the heat distributions [15]. These multicoil systems have been applied to both industrial [25-27] and domestic applications [44], [48], [68], and require the development of multiple-output inverters in order to obtain cost-effective solutions. Fig. 5 summarizes some of the approaches proposed. Fig. 5 (a) and (b) detail the schematic of a dual full-bridge inverter [47] and a dual half-bridge inverter [44], [60], respectively. These topologies have similar operation to their single-output counterpart, but with limited output power control due to additional ZVS constrains. Fig. 5 (c) shows a half-bridge topology featuring frequency selectable resonant loads [45]. Each resonant tank is tuned at a different resonant frequency, allowing selecting among them with the inverter operating frequency. Finally, Fig. 5 (d) shows the series resonant multi-inverter topology [48], [68] designed to supply IH systems with a high number of coils with a reduced number of switching devices, providing independent output power control in each load. Additionally, alternative conversion schemes have been recently studied for IH systems. Direct ac-ac conversion has been studied by some authors because of its benefits in terms of reduced component count and electromagnetic emissions (EMI), and improved efficiency. Fig. 6 summarizes some of the proposals made by several authors. In Fig. 6 (a) [64], several switching devices are combined to build bidirectional switches in order to implement a full-bridge direct ac-ac power converter. The main drawback is the increased number of switches, which increases the cost and complexity of the power converter. The power converter proposed in [57], Fig. 6 (b), follows the same procedure but using the recently developed reverse-blocking (RB) IGBTs to implement a half-bridge direct ac-ac converter with similar advantages and drawbacks than the previous implementation. In order to overcome these limitations, the proposals shown in Fig. 6 (c) and (d) were presented. On one hand, Fig. 6 (c) proposes a direct ac-ac half-bridge power converter featuring high-frequency rectifier diodes, which avoids the use of additional switching devices [52]. This power converter also increases the voltage applied to the load, increasing further the efficiency. Fig. 6 (d) shows a multipleoutput proposal where a common ac-ac converter block composed of the switching devices $\mathrm{S}_{\mathrm{mh}}$ and $\mathrm{S}_{\mathrm{ml}}$ is used to supply a large set of loads and, therefore, reducing the relative impact of the ac-ac block cost and complexity [49].

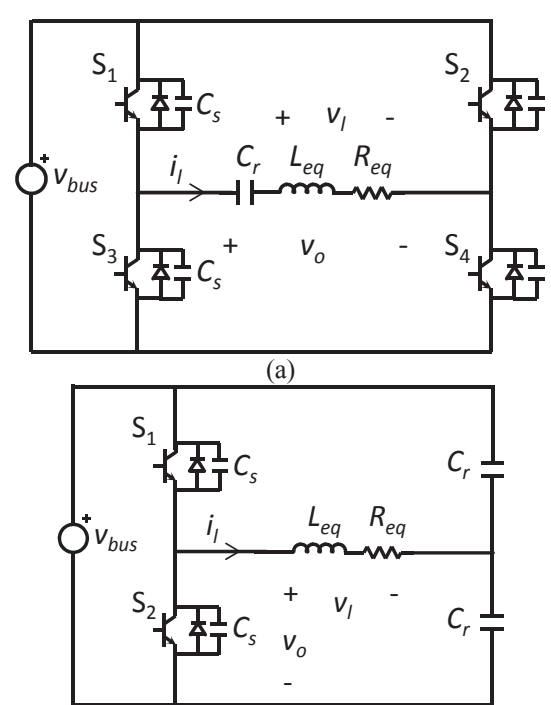

(b)

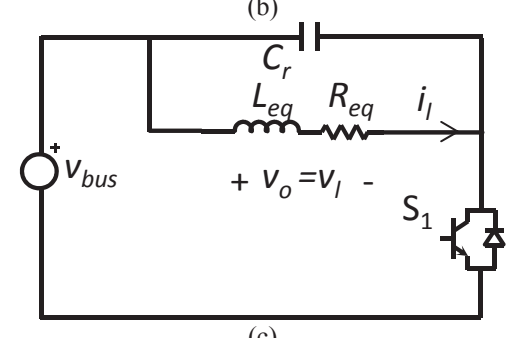

(c)

Fig. 4. Basic voltage source inverter topologies applied to IH: (a) fullbridge series resonant inverter, (b) half-bridge series resonant inverter, and (c) a single-switch ZVS quasi-resonant inverter.

\section{B. Modulation and control algorithms}

Modulation and control algorithms have to accurately control the power converter in order to obtain the desired performance. More specifically, accurate output power (and as consequence, temperature) and current control are required, with appropriate dynamics. The main issues to address, which are common to nearly any IH application, include the management of highly variable output power and IH loads and, more recently, the implementation of multi-coil systems.

In order to obtain an apropriate output power control from a static poing of view, different modulation types have been succesfully proposed for single phase systems: square wave [50], [69], [70], asymmetrical control [13], [50], [59], [66], [67] or pulse density modulation (PDM) [9], [14], [28], [29], [31], [59], [69]. Square wave and asymmetrical controls allow to change the output power in the complete operation range by either controlling the switching frequency or the duty cycle of the control signals. PDM, also known as burst mode, has the advantage of controlling the inverter at a fixed switching frequency by controlling the on-time of the inverter. The use of a phase-locked loop (PLL) is also common in the control schemes of IH inverters such as in [13], [74]. As an alternative to this idea, papers [25], [27] divide the control into two parts: direct phase control thanks to a PLL and indirect RMS amplitude control through a proportional-integral (PI) controler, as it can be seen in Fig. 7. This solution is possible 

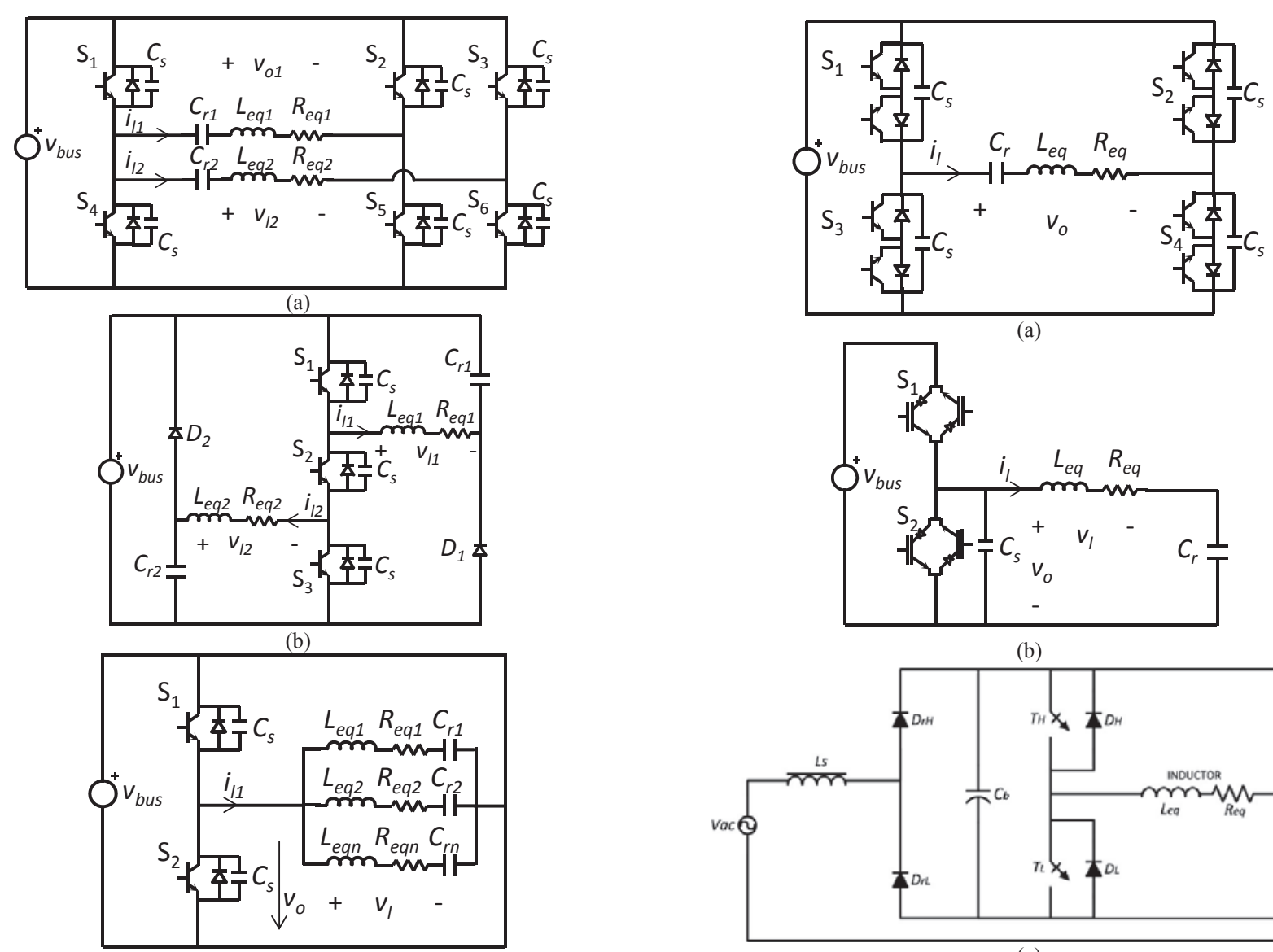

(c)

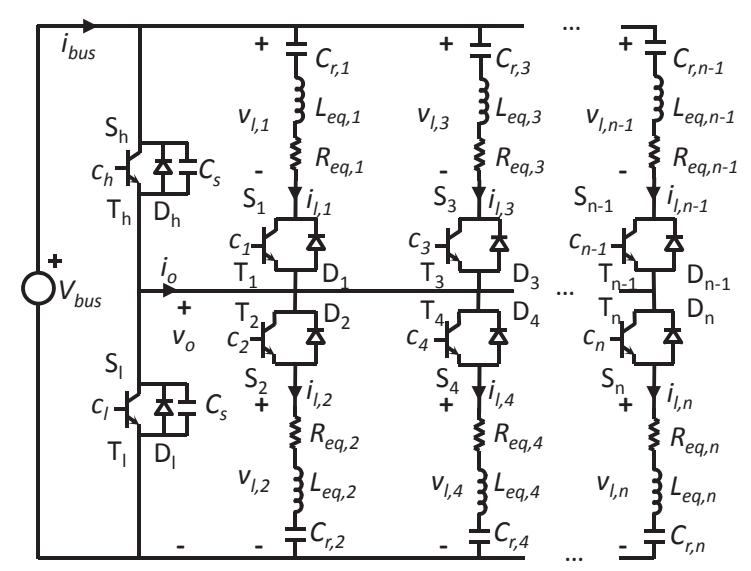

(d)

Fig. 5. Multiple-output inverters for multi-coil IH systems: (a) dual-full bridge, (b) dual output half-bridge, (c) frequencymultiplexed half bridge, and (d) series resonant multi-inverter.

in the case of one dc-dc converter per phase but the RMS calculation slows the dynamic response.

One of the issues for the future of IH is the load adaptive capabilities and some solutions have been proposed in [30], [94], [102]. An adaptive simmering control of the temperature for a domestic induction cooker is presented in [75]. Parameters are updated online, depending on the estimates (b)
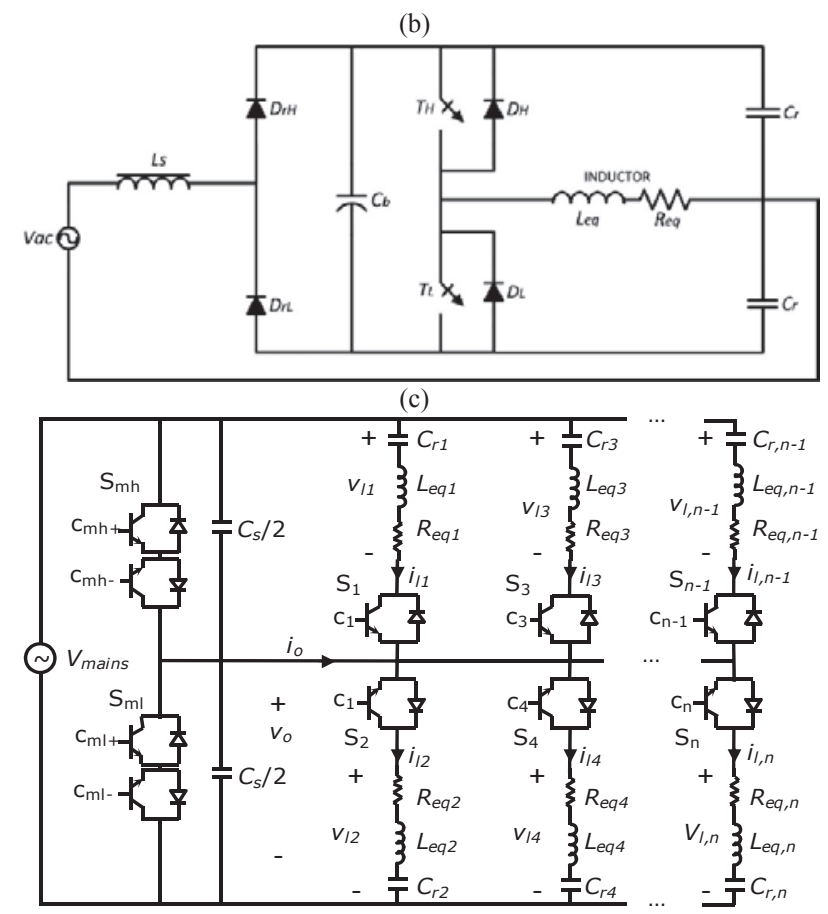

(d)

Fig. 6. Direct ac-ac resonant converters for IH systems: (a) fullbridge topology, (b) half-bridge topology featuring RB-IGBTs, (c) halfbridge topology featuring fast diode rectifiers, and (d) multiple-output ac-ac converter.

provided by a multiple-model reset observer (MMReO). This observer consists of a reinitialized reset observer and of multiple fixed identification models, as it can be seen in Fig. 8. Besides, a fixed robust quantitative feedback theory based controller is designed for comparison purposes. Such a control scheme achieves quick heating up and accurate temperature control whatever the amount of water, with or without a lid. 


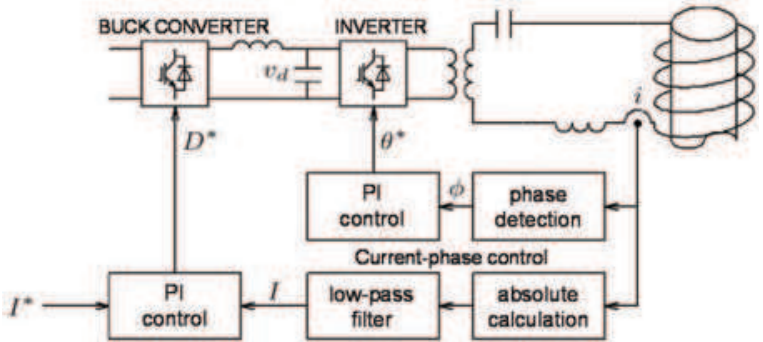

Fig. 7. Inductor current control circuit [25].

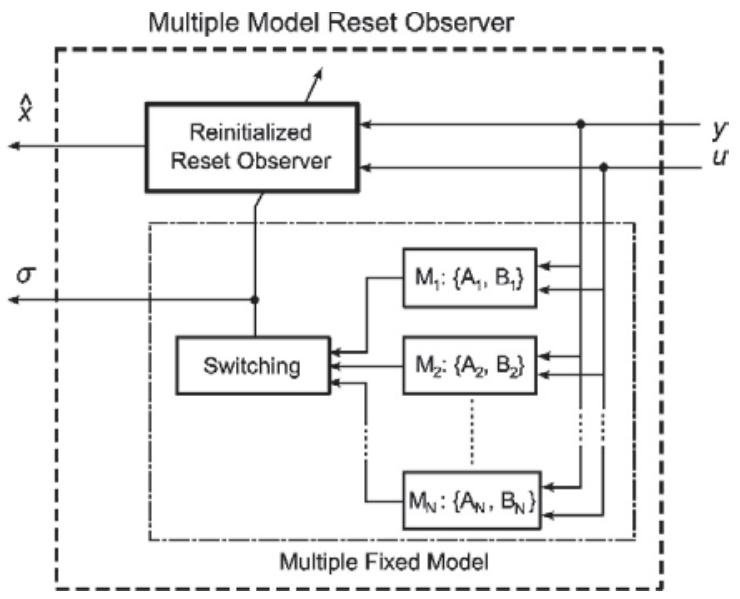

Fig. 8. Multi-model reset observer for ${ }^{\wedge} x=\left[{ }^{\wedge} \theta_{B},{ }^{\wedge} \theta_{W}\right]^{T}$ where $\theta_{B}$, and $\theta_{W}$ are the characteristic temperatures of the system [75].

Besides all the single phase architectures, multi-phase or multi-coil configurations could be helpful to increase either flexibility or power or even both simultaneously. Control becomes even more important since the currents have to be perfectly controlled in form, amplitude and phase, due to the coupling effects between the coils and with the load, whatever the configuration, transverse flux or longitudinal flux. Moreover, as the load characteristics changes with temperature, the controller task becomes heavy. An original control scheme is described and tested in [25-27] for a six-coil system called zone controlled induction heating $(\mathrm{ZCIH})$ in a longitudinal flux configuration. Paper [27] presents the use of a current control method based on a circuit model using real and imaginary (Re-Im) current/voltage components instead of the current amplitude and phase angle control in the classical approaches. State feedback decoupling provides separate current control on each phase with high dynamics but with a high computation burden due to numerous high rank matrix transformations. The six currents remain in phase in this application where no dc-dc converter is needed unlike in [25].

In order to obtain appropriate dynamics, resonant control of the inductor currents has been presented in [32] versus other classical control techniques for comparison purposes. With a highly reduced power electronic structure, the amplitudes and phases of the currents have to be precisely controlled in a CSI feeding a multi-coil IH system in transverse flux configuration. The innovation lies in the current phase control in order to fit a required temperature profile for metal treatment. A resonant controller is implemented on each of the phases of this multi-coil induction heating system in order to

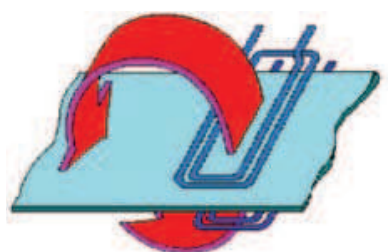

(a)

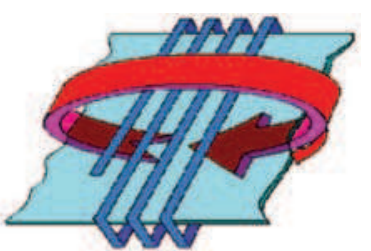

(b)
Fig. 9. Different inductor flux approaches: (a) transverse flux and (b) longitudinal flux.

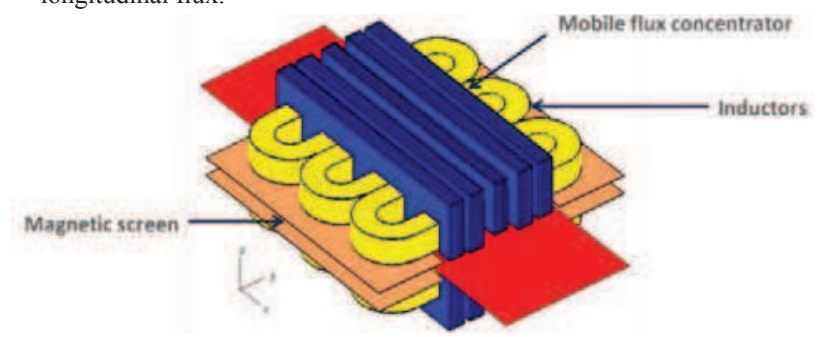

Fig. 10. Transverse flux induction heating with moving parts

achieve very fast and accurate control. Currents in the other phases are considered as disturbances that are compensated by each resonant controller.

All these modulation and control algorithms have been implemented either using analog [65] or digital techniques. Nowadays, digital implementations using digital signal processors (DSPs) or field-programmable gate arrays (FPGAs) due to their advantages in terms of configurability and performance. In particular, several design methodologies [33], monitoring [76] and control architectures [46], [72], [78], and accelerated simulation techniques [71] for $\mathrm{IH}$ systems have been proposed taken advantages of FPGAs.

\section{Magnetic component design}

The most important magnetic component in an IH system is the inductor-load system [42], [43]. Significant efforts have been paid to the modeling [34], [36], design, and optimization using either analytical [79] or finite element analysis (FEA). From an application point of view, the most important aspects are the electrical equivalent parameters extraction [44], [45], [80], [85] the efficiency optimization [81], [86-89], and the heat distribution optimization [26], [37], [38].

In the industrial applications of $\mathrm{IH}$, two different types of flux inductors exist, depending on the arrangements of the coil and the load and on the flux direction: transversal flux in Fig. 9 (a) or longitudinal flux in Fig. 9 (b).

The advantages of classical induction heating systems can be improved by multiphase inductors. Indeed, achieving metal temperature homogeneity with a single inductor on a large scale is impossible, particularly in transverse flux heating. A solution to overcome this constraint consists in using multicoil systems but with an increased complexity.

Conventional control solutions for industrial multiinductor systems [35], [39] are based on several inductors with mobile magnetic screens and mobile flux concentrators (Fig. 10). These additional devices adjust the magnetic fields produced and adapt the system to different formats of material and changes in position in order to reach the desired temperature gradients. The processing lines are then subject to 


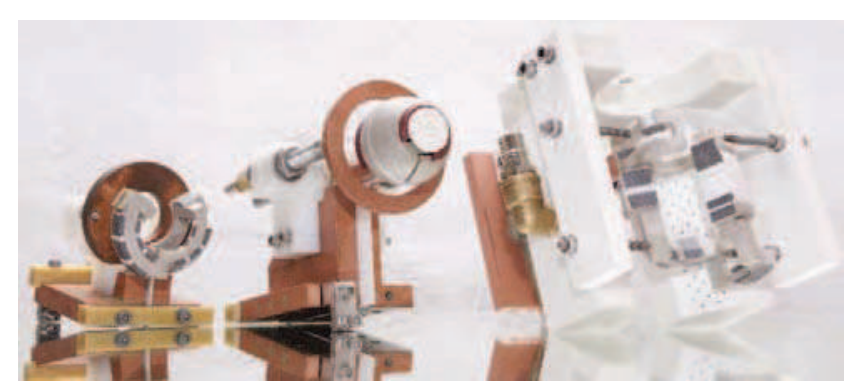

Fig. 11. Detail of several industrial water-cooled transverse flux inductors. Courtesy GH Electrotermia S.A.

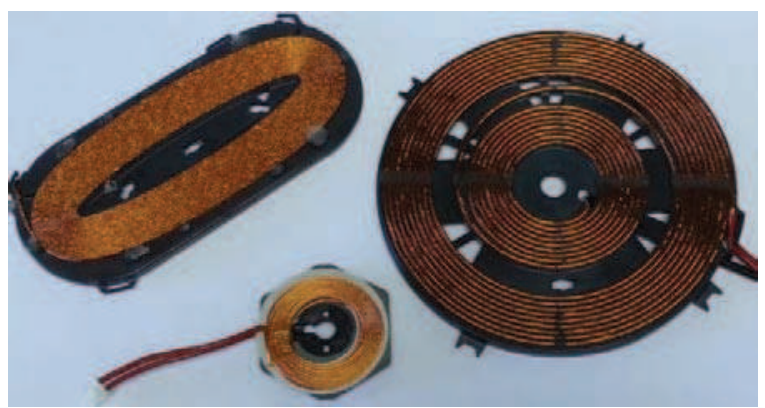

Fig. 12. Domestic induction heating inductors of different size and shape. Courtesy BSH Home Appliances Group.

mechanical adjustments and/or maintenance as often as necessary to change the material to be heated. It is important to notice that without any model, the desired power profile is obtained by successive trial and error setting tests which are time consuming.

Significant progresses [11], [25-27] have been made in this domain by considering a static multi-inductor system without any moveable devices such as yokes or magnetic screens. Nevertheless, these multi-coil systems involve mutual coupling between inductors themselves and between the inductors and the load that have to be taken into account in the control scheme [27], [82-84]. The corresponding architectures often present rather complex solutions with one $\mathrm{dc}-\mathrm{dc}$ converter (or one rectifier) plus one resonant inverter per phase as in [11], [25-27]. In [40], it is proposed to manually change the coil connections for load-generator adaptation. Some decoupling transformers between the different phases are added in [41], which are certainly bulky and costly. It is possible to take advantage of simpler structures by an optimization with constraints, based on a prior determination of the mapping of induced current distribution inside the heated material. It necessitates the global power density calculation in order to achieve the correct temperature profile through the setting of currents in the 3 phases in [30]. In that case, amplitudes and phases of the inductor currents have to be determined and controlled.

Fig. 11 shows an example of several water-cooled inductors for industrial applications, whereas Fig. 12 shows several flat inductors with different shapes and sizes for domestic induction heating.

This Section has covered the main enabling technologies in IH systems. Next Section will explain the main applications of IH with a special focus on the differential characteristics and the implemented technologies.

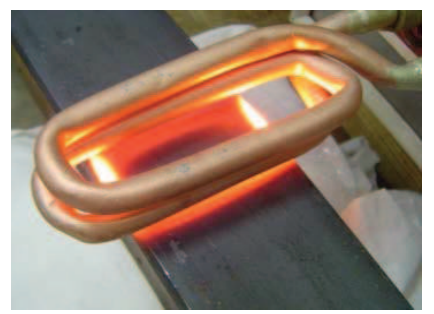

(a)

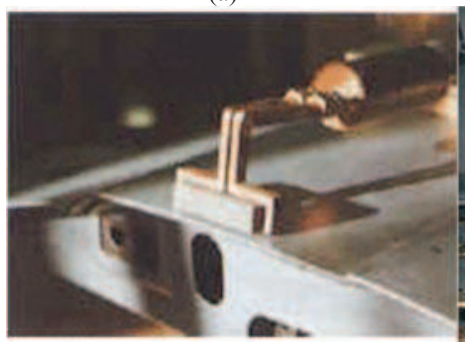

(c)

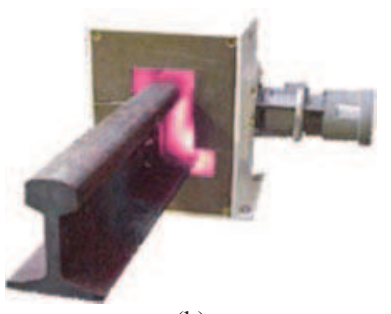

(b)

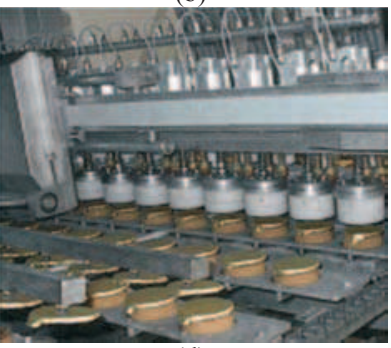

(d)
Fig. 13. Example of IH applications: (a) IH metal by transverse flux, (b) $\mathrm{IH}$ of rails for hardening, (c) bonding by $\mathrm{IH}$, and (d) sealing by IH. Courtesy Five Celes.
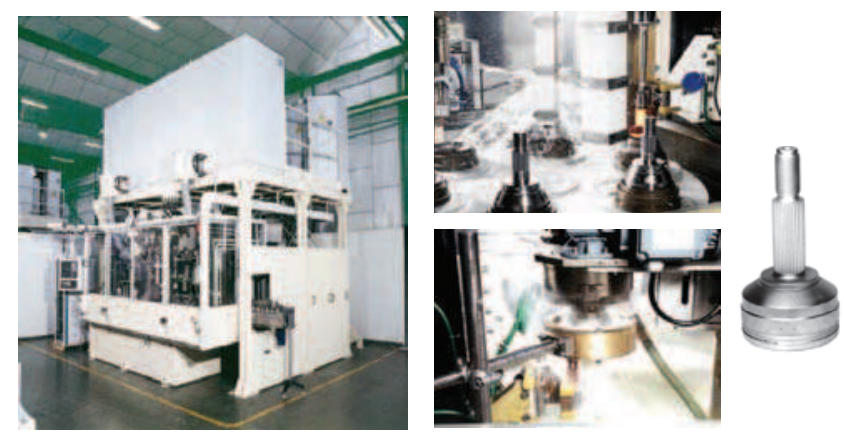

Fig. 14. Industrial applications of induction heating: IH joints hardening facility for the automotive industry. Courtesy GH Electrotermia S.A.

\section{INDUCTION HEATING APPLICATIONS}

Among the many applications of induction heating, industrial, domestic and medical are the most important in terms of installed power and economic importance. The next subsections details the main characteristics of these IH applications.

\section{A. Industrial applications}

Industrial applications of IH started in the early 1900s with metal melting and were later extended to the automotive and aircraft industries. Current applications have been extended to many manufacturing processes including preand post-heating, melting, forging, surface treatment, sealing, bonding, annealing, and welding, among others.

The use of induction heating improves the speed of the process, its precision, efficiency, and repeatability, which are key features needed for the automation of the industrial processes. Fig. 14 shows two complete induction heating installation for joints hardening (a) and tube welding (b). Other industrial applications can be seen in Fig. 13 (a) and (b), for high power level, or in Fig. 13 (c) and (d), for lower 


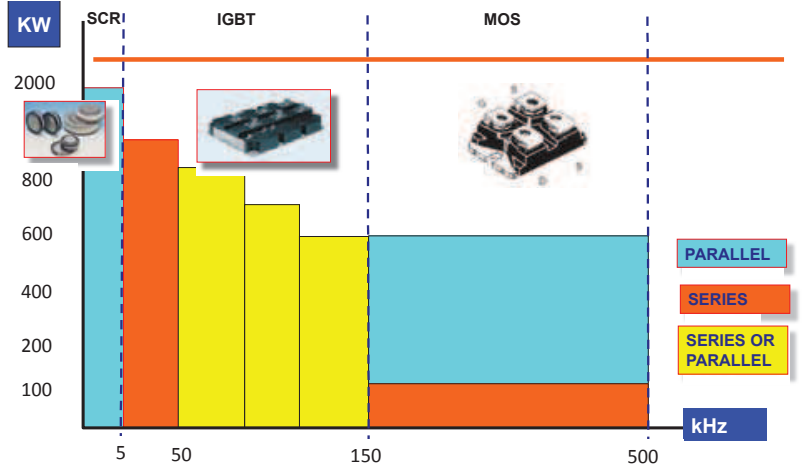

Fig. 15. Power devices used in industrial IH applications.

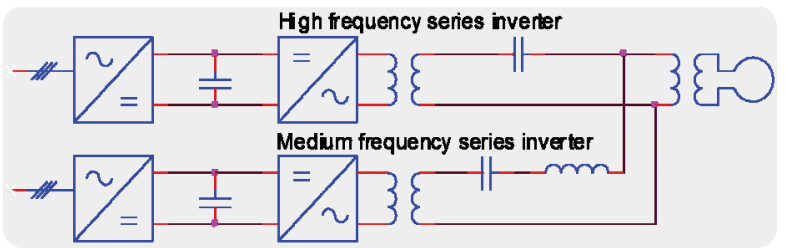

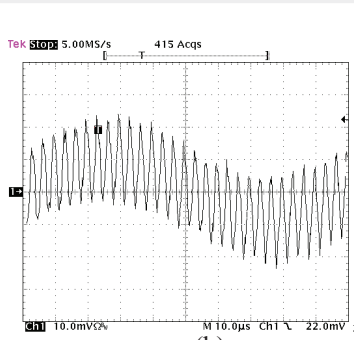

(b)

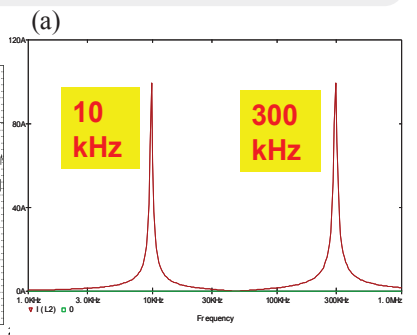

(c)
Fig. 16. Double-frequency induction heating generator: (a) block diagram, (b) output current ( $25 \mathrm{~A} / \mathrm{div}$, time $10 \mu \mathrm{s} / \mathrm{div}$ ), and (c) output current spectrum.

power levels. The method in Fig. 13 (c) consists in accelerating the polymerization of the glue by heating the metal parts to be glued by induction. The temperatures required are generally low $\left(150\right.$ to $\left.300^{\circ} \mathrm{C}\right)$. Fig. 13 (d) is an elegant means of sealing aluminum covers on jars of food product. Inductive heating of the aluminum film increases the temperature of the sealing product applied to the side of the cover in contact with the jar.

Depending on the final application and the material to heat, the power converter operating frequency is significantly different, varying from a few $\mathrm{Hz}$ for high power systems, typical for metal melting, to several hundreds of $\mathrm{kHz}$, for surface heat processing. As a consequence, semiconductors used in industrial heating converters are thyristors, operating at frequencies up to $3 \mathrm{kHz}$, for power ratings of several MWs, while IGBTs, operating at frequencies up to $150 \mathrm{kHz}$

for power ratings up to $3 \mathrm{MW}$ are normally used. MOSFETs are used for higher frequencies, up to several hundreds of $\mathrm{kHz}$ and output powers lower than $500 \mathrm{~kW}$. Fig. 15 summarizes the semiconductor device utilization area depending on the switching frequency, the power level, and the type of resonant tank, series or parallel, used.

Certain applications require more advanced topologies that aim to improve the heating characteristics or expanding

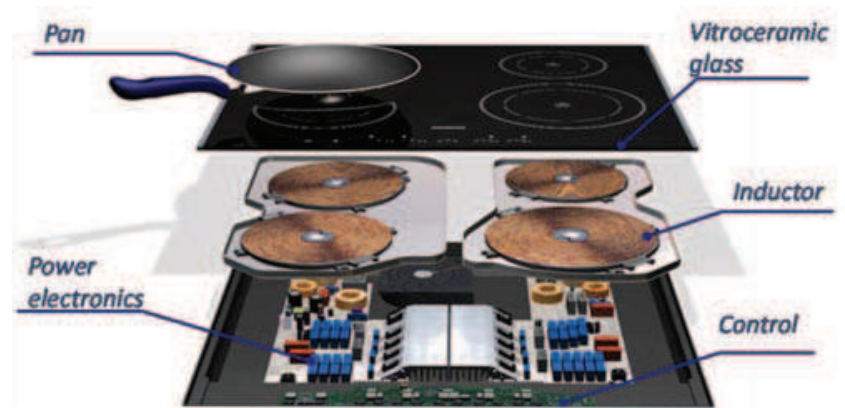

(a)

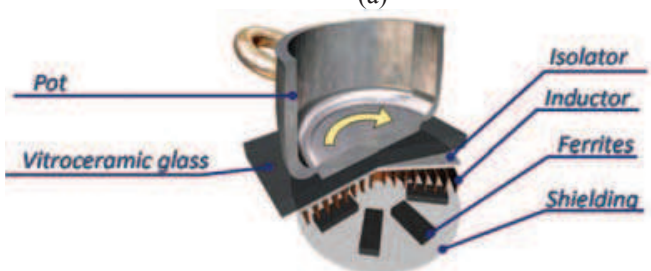

(b)

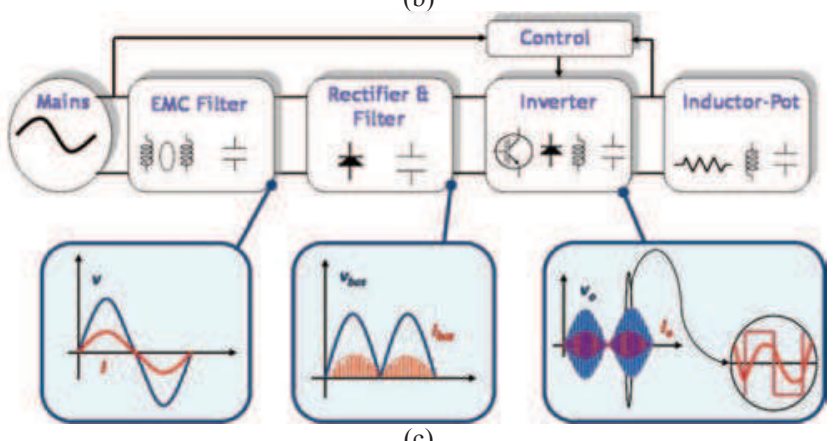

(c)

Fig. 17. Induction heating appliances: (a) exploded view, (b) inductor system detail, and (c) power conversion diagram.

into new fields of application. This is the case of the dual frequency generators [22] used to feed the inductor, sequentially or simultaneously, with two different frequencies (Fig. 16) to achieve different penetration depths. One frequency is typically set in the medium frequency range ( 3 to $10 \mathrm{kHz})$, and the other one in the high frequency range (200 to $400 \mathrm{kHz}$ ). These types of generators are used for hardening work pieces with irregular surface geometry like gears.

It is important to note that control and interoperability of industrial IH systems are extremely important. On the one hand, the power converter operation must be accurately controlled to obtain the desired results in the IH target. On the other hand, the $\mathrm{IH}$ system must be interconnected to the complete assembly line using industrial protocols such as Profinet, Interbus, Profibus, etc.

\section{B. Domestic applications}

The main domestic applications of $\mathrm{IH}$ are the induction heating appliances [62]. IH cookers take advantage not only of improved heating times and efficiency, but also lower surface temperatures, which implies better security and cleanness, since food does not get burnt.

Fig. 17 shows the main structure of an IH appliance (a) and a detail of the inductor-pot system (b). The main characteristics of this application is the low-profile compact 


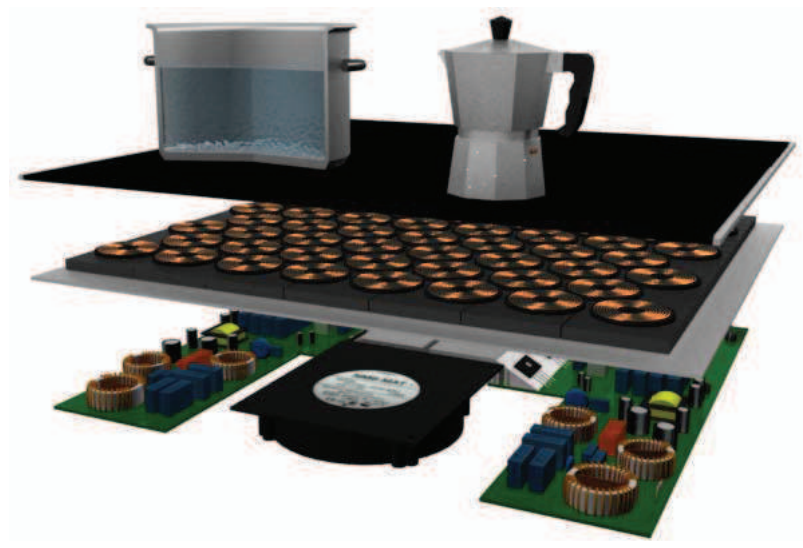

Fig. 18. Total active surface IH Appliance.

design, and the highly variable IH target, which can change in shape, materials, and position very easily. Efficiency is also a key design parameter due to the limited cooling capabilities. For this reason, large efforts have been paid to improve the power converter and inductor efficiency [50-52], [54], [55], [61].

Nowadays, two technological trends are present in IH appliances. Both of them follow the same power conversion diagram shown in Fig. 17 (c), but differ in the inverter topology. Designs for Europe and America are usually specified for output powers up to $4 \mathrm{~kW}$, and the power converter topology usually chose is the series resonant halfbridge inverter [50], [56]. By contrast, appliances for Asiatic countries are usually designed with $2 \mathrm{~kW}$ output power and the preferred topology is the ZVS single-switch quasiresonant inverter [58]. In addition to this, this technology also offers the capability to heat high-conductivity materials [53], such as aluminum or copper, usually employed in these countries. Taking into account the output power and cost restrictions, switching frequencies usually ranges from $20 \mathrm{kHz}$ up to $100 \mathrm{kHz}$. The lower limit is set in order to avoid acoustic noise emissions, not desirable in domestic applications, whereas the higher limit is imposed by the switching losses of the power devices.

These appliances feature also advanced control techniques including smart pot recognition [76] and adaptive control strategies [75] to control not only the output power but also the pot temperature. It provides the user with advanced functionalities that cannot be achieved with conventional cookers, significantly improving the user performance.

Currently, research trends are focused on higher efficiency power converters and flexible cooking surfaces technology [9], [52], [61], [86], where a special effort is required to design multiple-output power converters and compact coils [44], [48], [83]. The total active surface concept (Fig. 18), still under development, is an example of modern development where the user can place any pot, with any shape, anywhere in the cooking surface, redefining completely the cooking experience. This new concept requires the development of high-efficiency high-performance multiple output power converters to satisfy the required specifications with a costeffective solution. Besides, the control and modulation strategies become more complex since accurate multi-load management is required. This is a remarkable example of how advances in enabling technologies leads to improved induction heating systems present in the market.

\section{Medical applications}

Nowadays, the third major area of application of $\mathrm{IH}$ technology is related to its medical applications. Initially, IH was applied in the manufacturing and sterilization of many surgical instruments, since it is a clean, fast, and portable heat source. However, in recent years IH has also been introduced in some minimally-invasive therapies [3].

Hyperthermia is a cancer treatment therapy based on heating the target tumor temperatures over $50^{\circ} \mathrm{C}$. This local treatment removes cancer tissue while minimizing the damage to surrounding healthy cells. IH is therefore a good alternative for hyperthermia treatments because it is a contactless heating technique, i.e. less invasive, and provides accurate power control. In order to precisely deliver the power the tumor, usually a ferromagnetic material is placed in the area to be treated. Modern research trends investigate about the use of fluids with ferromagnetic nanoparticles in order to obtain precise heat distributions [93-97]. These techniques require the design of accurate power converters and control [90-92], and specific inductor designs [3], [98]. Due to the typical low resistivity nature of $\mathrm{IH}$ loads for medical applications, parallel resonant inverters are applied in order to minimize the current through the inverter. Besides, the operating frequencies are set to be higher than $300 \mathrm{kHz}$ up to several $\mathrm{MHz}$ to obtain appropriate equivalent electrical parameters, being the MOSFET the power device commonly implemented.

Future research include more precise and homogeneous heating, and temperature monitoring in the cancer and surrounding tissues, along with combining this technique with other therapies to improve results.

\section{Future CHALlenges}

Although IH systems have reached certain maturity, there are still some issues to address to further increase its performance. Moreover, advances in enabling technologies and applications continuously open new research trends and industrial interest. Among the many topics of interest, significant efforts are expected in these topics in the next years:

- High-efficiency IH systems: the improvement of semiconductor technology and the development of widebandgap devices, together with advanced topologies, are allowing the design of higher efficiency systems. Such systems not only exhibit higher efficiency, but also improved performance and reliability.

- Multi-coil IH systems: Multi-coil systems offer higher flexibility, performance, and heat distribution, and are essential for some high precision/flexibility industrial and domestic applications. These systems represent a major breakthrough in IH technology, requiring the development of multiple-output power converters, advanced control techniques, and special inductor design paying very high attention to coupling effects.

- Advanced control systems: IH systems require robust control algorithms to adapt the power converter operation 
to different $\mathrm{IH}$ loads and operating points. Current research lines pursue the use of adaptive algorithms and real-time identification systems to improve the system performance. This is one of the key issues of multi-coil systems as well as real time temperature measurement and optimal control and stability study. Generalized averaging methods and envelope models will help to fix the characteristics of the current transients in these systems.

- Special applications: although the process parameters in many industrial and domestic applications are already well-known, there are still some applications that need further research and optimization to find viable solutions. Among these special applications, the following are worth to be highlighted: heating of low-resistivity materials, accurate heating of biological tissues for medical applications, faster design of IH systems for complex IH load geometries, and accurate 3D FEA simulation of the complete IH system.

\section{CONCLUSIONS}

This paper has reviewed the current state-of-art of induction heating systems, focusing on the enabling technologies involved and the main applications, and providing an exhaustive list of papers.

From a design point of view, there are three main enabling technologies to tackle when designing an IH system: power converter, modulation and control architecture, and the inductor design. Extensive research has been carried out in recent years, leading to improved $\mathrm{IH}$ systems that have enabled widening IH systems usage to many industrial, domestic, and medical applications.

The future of $\mathrm{IH}$ systems is promising, with new technologies and applications fostering research in each one of the three enabling technologies aforementioned. The development of higher efficiency and performance IH systems is expected to be the focus of industrial interest and researches, further increasing the general interest in IH systems.

\section{REFERENCES}

[1] M. G. Lozinskii, Industrial Applications of Induction Heating, [1st English ed. Oxford, New York,: Pergamon Press, 1969.

[2] W. C. Moreland, "The induction range: its performance and its development problems," IEEE Transactions on Industry Applications, vol. 9, no. 1, pp. 81-85, Jan./Feb. 1973.

[3] P. R. Stauffer, T. C. Cetas, and R. C. Jones, "Magnetic Induction Heating of Ferromagnetic Implants for Inducing Localized Hyperthermia in Deep-Seated Tumors," IEEE Transactions on Biomedical Engineering, vol. BME-31, no. 2, pp. 235-251, February 1984

[4] G. H. Brown, C. N. Hoyler, and R. A. Bierwirth, Theory and Application of Radio-Frequency Heating. New York,: Van Nostrand, 1947.

[5] J. W. Cable, Induction and Dielectric Heating. New York,: Reinhold, 1954.

[6] V. Rudnev, D. Loveless, R. Cook, and M. Black, Handbook of induction heating. New York: Marcel Dekker Inc., 2003.

[7] J. Davies, Conduction and Induction heating. London: Peter Peregrinus Ltd., 1990.

[8] A. Mühlbauer, History of Induction Heating and Melting. Essen: Vulkan-Verlag $\mathrm{GmbH}, 2008$

[9] V. Esteve, et al., "Improving the efficiency of IGBT series-resonant inverters using pulse density modulation," IEEE Transactions on Industrial Electronics, vol. 58 , no. 3, pp. 979-987, March 2011 .

[10] J. M. Espi Huerta, E. J. Dede Garcia Santamaria, R. Garcia Gil, and J. Castello Moreno, "Design of the L-LC resonant inverter for induction heating based on its equivalent SRI," IEEE Transactions on Industrial Electronics, vol. 54, no. 6, pp. 3178-3187, December 2007.

[11] H. Fujita, N. Uchida, and K. Ozaki, "A new zone-control induction heating system using multiple inverter units applicable under mutual magnetic coupling conditions," IEEE Transactions on Power Electronics, vol. 26, no. 7, pp. 20092017, July 2010.
[12] I. Yilmaz, M. Ermis, and I. Cadirci, "Medium-frequency induction melting furnace as a load on the power system," IEEE Transactions on Industry Applications, vol. 48, no. 4, pp. 1203-1214, July/August 2012.

[13] S. Chudjuarjeen, A. Sangswang, and C. Koompai, "An improved LLC resonant inverter for induction-heating applications with asymmetrical control," IEEE Transactions on Industrial Electronics, vol. 58, no. 7, pp. 2915-2925, July 2011.

[14] N. A. Ahmed, "High-frequency soft-switching ac conversion circuit with dualmode PWM/PDM control strategy for high-power IH applications," IEEE Transactions on Industrial Electronics, vol. 58, no. 4, pp. 1440-1448, April 2011.

[15] J. I. Rodriguez and S. B. Leeb, "Nonresonant and resonant frequency-selectable induction-heating targets," IEEE Transactions on Industrial Electronics, vol. 57, no. 9 , pp. 3095-3108, September 2010.

[16] J. I. Rodriguez and S. B. Leeb, "A multilevel inverter topology for inductively coupled power transfer," IEEE Transactions on Power Electronics, vol. 21, no. 6, pp. 1607-1617, 2006

[17] N. R. Stansel, Induction Heating, 1st ed. New York,: McGraw-Hill, 1949.

[18] F. P. Dawson and P. Jain, "A comparison of load commutated inverter systems for induction heating and melting applications," IEEE Transactions on Power Electronics, vol. 6, no. 3, pp. 430-441, July 1991.

[19] H. W. Koertzen, J. D. v. Wyk, and J. A. Ferreira, "Design of the half-bridge series resonant converters for induction cooking," in IEEE Power Electronics Specialist Conference Records, 1995, pp. 729-735.

[20] M. Kamli, S. Yamamoto, and M. Abe, "A 50-150 kHz half-bridge inverter for induction heating applications," IEEE Transactions on Industrial Electronics, vol. 43, no. 1, pp. 163-172, February 1996.

[21] E. J. Dede, J. V. Gonzalez, J. A. Linares, J. Jordan, D. Ramirez, and P. Rueda, "25-kW/50-kHz generator for induction heating," IEEE Transactions on Industrial Electronics, vol. 38, no. 3, pp. 203-209, June 1991.

[22] V. Esteve, J. Jordan, E. J. Dede, E. Sanchis-Kilders, and E. Maset, "Induction heating inverter with simultaneous dual-frequency output," in IEEE Applied Power Electronics Conference and Exposition, 2006, p. 5 pp.

[23] M. K. Kazimierczuk and D. Czarkowski, Resonant Power Converters. New York: John Willey \& Sons, 1995.

[24] R. L. Steigerwald, "A comparison of half-bridge resonant converter topologies," IEEE Transactions on Power Electronics, vol. 3, no. 2, pp. 174-182, April 1988.

[25] H. Pham, H. Fujita, K. Ozaki, and N. Uchida, "Phase angle control of highfrequency resonant currents in a multiple inverter system for zone-control induction heating," IEEE Transactions on Power Electronics, vol. 26, no. 11, pp. 3357-3366, 2011.

[26] H. N. Pham, H. Fujita, K. Ozaki, and N. Uchida, "Estimating method of heat distribution using 3-D resistance matrix for zone-control induction heating systems," IEEE Transactions on Power Electronics, vol. 27, no. 7, pp. 33743382 , July 2012

[27] H. N. Pham, H. Fujita, K. Ozaki, and N. Uchida, "Dynamic analysis and control for resonant currents in a zone-control induction heating system," IEEE Transactions on Power Electronics, vol. 28, no. 3, pp. 1297-1307, March 2013.

[28] H. Fujita and H. Akagi, "Pulse-density-modulated power control of a 4 kW, 450 $\mathrm{kHz}$ voltage-source inverter for induction melting applications," IEEE Transactions on Industry Applications, vol. 32, no. 2, pp. 279-286, March/April 1996.

[29] H. Fujita and H. Akagi, "Control and performance of a pulse-density-modulated series-resonant inverter for corona discharge processes," IEEE Transactions on Industry Applications, vol. 35, no. 3, pp. 621-627, May/June 1999.

[30] J. Egalon, S. Caux, P. Maussion, M. Souley, and O. Pateau, "Multiphase system for metal disc induction heating: Modeling and RMS current control," IEEE Transactions on Industry Applications, vol. 48, no. 5, pp. 1692-1699, September/October 2012.

[31] N. Park, D. Lee, and D. Hyun, "A power-control scheme with constant switching frequency in class-D inverter for induction-heating jar application," IEEE Transactions on Industrial Electronics, vol. 54, no. 3, pp. 1252-1260, June 2007.

[32] L. Nguyen Kien, S. Caux, X. Kestelyn, O. Pateau, and P. Maussion, "Resonant control of multi-phase induction heating systems," in Annual Conference on IEEE Industrial Electronics Society IECON, 2012, pp. 3293-3298.

[33] D. Navarro, O. Lucía, L. A. Barragán, I. Urriza, and O. Jiménez, "High-level synthesis for accelerating the FPGA implementation of computationallydemanding control algorithms for power converters," IEEE Transactions on Industrial Informatics, no. 2013.

[34] F. Dughiero, M. Forzan, C. Pozza, and E. Sieni, "A translational coupled electromagnetic and thermal innovative model for induction welding of tubes," IEEE Transactions on Magnetics, vol. 48, no. 2, pp. 483-486, 2012.

[35] F. Caricchi, F. Maradei, G. De Donato, and F. G. Capponi, "Axial-flux permanent-magnet generator for induction heating gensets," IEEE Transactions on Industrial Electronics, vol. 57, no. 1, pp. 128-137, January 2010.

[36] R. Benato, F. Dughiero, M. Forzan, and A. Paolucci, "Proximity effect and magnetic field calculation in GIL and in isolated phase bus ducts," IEEE Transactions on Magnetics, vol. 38, no. 2, pp. 781-784, 2002.

[37] A. Candeo, C. Ducassy, P. Bocher, and F. Dughiero, "Multiphysics modeling of induction hardening of ring gears for the aerospace industry," IEEE Transactions on Magnetics, vol. 47, no. 5, pp. 918-921, May 2011.

[38] A. Aliferov, F. Dughiero, and M. Forzan, "Coupled magneto-thermal FEM model of direct heating of ferromagnetic bended tubes," IEEE Transactions on Magnetics, vol. 46, no. 8, pp. 3217-3220, August 2010. 
[39] T. Tudorache and V. Fireteanu, "Magneto-thermal-motion coupling in transverse flux heating," COMPEL: The International Journal for Computation and Mathematics in Electrical and Electronic Engineering, vol. 27, no. 2, pp. 399407, 2008.

[40] S. O. Fishman, R. K. Lampi, J. H. Mortimer, and V. A. Peyshakhovich, "Induction heating device and process for controlling temperature distribution," WO Patent WO200028787 May, 2000.

[41] N. Uchida, K. Kawanaka, H. Nanba, and K. Ozaki, "Induction heating method and unit," US Patent 2007012577107 June, 2000.

[42] W. Hurley and J. Kassakian, "Induction heating of circular ferromagnetic plates," IEEE Transactions on Magnetics, vol. 15, no. 4, pp. 1174-1181, July 1979.

[43] M. K. Kazimierczuk, High-Frequency Magnetic Components. New York: John Willey \& Sons, 2009.

[44] F. Forest, S. Faucher, J.-Y. Gaspard, D. Montloup, J.-J. Huselstein, and C. Joubert, "Frequency-synchronized resonant converters for the supply of multiwindings coils in induction cooking appliances," IEEE Transactions on Industrial Electronics, vol. 54, no. 1, pp. 441-452, February 2007.

[45] F. Forest, E. Labouré, F. Costa, and J.-Y. Gaspard, "Principle of a multiload/single converter system for low power induction heating," IEEE Transactions on Industrial Electronics, vol. 15, no. 2, pp. 223-230, March 2000

[46] O. Lucía, L. A. Barragán, J. M. Burdío, O. Jiménez, D. Navarro, and I. Urriza, "A versatile power electronics test-bench architecture applied to domestic induction heating," IEEE Transactions on Industrial Electronics, vol. 58, no. 3, pp. 998-1007, March 2011.

[47] J. M. Burdío, F. Monterde, J. R. García, L. A. Barragán, and A. Martínez, "A two-output series-resonant inverter for induction-heating cooking appliances," IEEE Transactions on Power Electronics, vol. 20, no. 4, pp. 815-822, July 2005.

[48] O. Lucía, J. M. Burdío, L. A. Barragán, J. Acero, and I. Millán, "Series-resonant multiinverter for multiple induction heaters," IEEE Transactions on Power Electronics, vol. 24, no. 11, pp. 2860-2868, November 2010.

[49] O. Lucía, C. Carretero, J. M. Burdío, J. Acero, and F. Almazán, "Multiple-output resonant matrix converter for multiple induction heaters," IEEE Transactions on Industry Applications, vol. 48, no. 4, pp. 1387-1396, July/August 2012.

[50] O. Lucía, J. M. Burdío, I. Millán, J. Acero, and L. A. Barragán, "Efficiency oriented design of ZVS half-bridge series resonant inverter with variable frequency duty cycle control," IEEE Transactions on Power Electronics, vol. 25, no. 7, pp. 1671-1674, July 2010.

[51] H. Sarnago, O. Lucía, A. Mediano, and J. M. Burdío, "Class-D/DE dual-modeoperation resonant converter for improved-efficiency domestic induction heating system," IEEE Transactions on Power Electronics, vol. 28, no. 3, pp. 1274-1285, 2013.

[52] H. Sarnago, A. Mediano, and O. Lucía, "High efficiency ac-ac power electronic converter applied to domestic induction heating," IEEE Transactions on Power Electronics, vol. 27, no. 8, pp. 3676-3684, August 2012.

[53] A. Fujita, H. Sadakata, I. Hirota, H. Omori, and M. Nakaoka, "Latest developments of high-frequency series load resonant inverter type built-in cooktops for induction heated all metallic appliances," in IEEE Power Electronics and Motion Control Conference, 2009, pp. 2537-2544.

[54] N. A. Ahmed and M. Nakaoka, "Boost-half-bridge edge resonant soft switching PWM high-frequency inverter for consumer induction heating appliances," IEE Proceedings on Electric Power Applications, vol. 153, no. 6, pp. 932-938, 2006

[55] H. Kifune, Y. Hatanaka, and M. Nakaoka, "Quasi-series-resonant-type softswitching phase shift modulated inverter," IEE Proceedings on Electric Power Applications, vol. 150, no. 6, pp. 725-732, June 2003.

[56] K. Ogura, et al., "Performance evaluation of edge-resonant ZVS-PWM highfrequency inverter using trench-gate IGBTs for consumer induction cooking heater," IEE Proceedings on Electric Power Applications, vol. 151, no. 5, pp. 563-568, 2004

[57] H. Sugimura, S.-P. Mun, S.-K. Kwon, T. Mishima, and M. Nakaoka, "Highfrequency resonant matrix converter using one-chip reverse blocking igbt-based bidirectional switches for induction heating," in IEEE Power Electronics Specialists Conference, 2008.

[58] S. Wang, K. Izaki, I. Hirota, H. Yamashita, H. Omori, and M. Nakaoka, "Induction-heated cooking appliance using new quasi-resonant ZVS-PWM inverter with power factor correction," IEEE Transactions on Industry Applications, vol. 34, no. 4, pp. 705-712, July/August 1998.

[59] B. Saha, K. Soon Kurl, N. A. Ahmed, H. Omori, and M. Nakaoka, "Commercial frequency $\mathrm{AC}$ to high frequency $\mathrm{AC}$ converter with boost-active clamp bridge single stage ZVS-PWM inverter," IEEE Transactions on Power Electronics, vol. 23, no. 1, pp. 412-419, January 2008

[60] Y.-C. Jung, "Dual half bridge series resonant inverter for induction heating appliance with two loads," Electronics Letters, vol. 35, no. 16, pp. 1345-1346, May 1999.

[61] H. Sarnago, O. Lucía, A. Mediano, and J. M. Burdío, "High efficiency parallel quasi-resonant current source inverter featuring SiC MOSFETs for induction heating systems with coupled inductors," IET Power Electronics, no. 2013.

[62] J. Acero, et al., "Domestic Induction Appliances," IEEE Industry Applications Magazine, vol. 16, no. 2, pp. 39-47, March/April 2010.

[63] H. W. Koertzen, J. A. Ferreira, and J. D. van Wyk, "A comparative study of single switch induction heating converters using novel component effectivity conceps," in IEEE Power Electronics Specialists Conference, 1992, pp. 298-305.
[64] N. Nguyen-Quang, D. A. Stone, C. M. Bingham, and M. P. Foster, "Single phase matrix converter for radio frequency induction heating," in IEEE International Symposium on Power Electronics, Electrical Drives, Automation and Motion, 2006, pp. 614-618.

[65] J. I. Artigas, I. Urriza, J. Acero, L. A. Barragán, D. Navarro, and J. M. Burdío, "Power measurement by output-current integration in series resonant inverters," IEEE Transactions on Industrial Electronics, vol. 56, no. 2, pp. 559-567, February 2009.

[66] L. A. Barragán, J. M. Burdío, J. I. Artigas, D. Navarro, J. Acero, and D. Puyal, "Efficiency optimization in ZVS series resonant inverters with asymmetrical voltage-cancellation control," IEEE Transactions on Power Electronics, vol. 20, no. 5, pp. 1036-1044, September 2005.

[67] J. M. Burdío, L. A. Barragán, F. Monterde, D. Navarro, and J. Acero, "Asymmetrical voltage-cancelation control for full-bridge series resonant inverters," IEEE Transactions on Power Electronics, vol. 19, no. 2, pp. 461-469, March 2004.

[68] O. Lucía, J. M. Burdío, L. A. Barragán, J. Acero, and C. Carretero, "Series resonant multi-inverter with discontinuous-mode control for improved light-load operation," IEEE Transactions on Industrial Electronics, vol. 58, no. 11, pp. 5163-5171, November 2011.

[69] O. Lucía, J. M. Burdío, I. Millán, J. Acero, and D. Puyal, "Load-adaptive control algorithm of half-bridge series resonant inverter for domestic induction heating," IEEE Transactions on Industrial Electronics, vol. 56, no. 8, pp. 3106-3116, August 2009.

[70] H. Sarnago, O. Lucía, A. Mediano, and J. M. Burdío, "Modulation scheme for improved operation of a RB-IGBT based resonant inverter applied to domestic induction heating," IEEE Transactions on Industrial Electronics, vol. 60, no. 5, pp. 2066-2073, May 2013.

[71] O. Lucía, I. Urriza, L. A. Barragan, D. Navarro, O. Jiménez, and J. M. Burdío, "Real-time FPGA-based hardware-in-the-loop simulation test-bench applied to multiple output power converters," IEEE Transactions on Industry Applications, vol. 47, no. 2, pp. 853-860, March/April 2011.

[72] D. Navarro, O. Lucía, L. A. Barragán, J. I. Artigas, I. Urriza, and O. Jiménez, "Synchronous FPGA-based implementations of digital pulse width modulators," IEEE Transactions on Power Electronics, vol. 27, no. 5, pp. 2515-2525, May 2012.

[73] Y. Kawaguchi, et al, "A comparative evaluation of DCM control and CCM control for soft-switching PFC converter," in 36th Annual Conference of the IEEE Industrial Electronics Society, 2010, pp. 250-255.

[74] J. Tian, G. Berger, T. Reimann, M. Scherf, and J. Petzoldt, "A half-bridge series resonant inverter for induction cookers using a novel FPGA-based control strategy," in European Conference on Power Electronics and Applications, 2005, pp. 9 pp.-P.9

[75] D. Paesa, C. Franco, S. Llorente, G. Lopez-Nicolas, and C. Sagues, "Adaptive Simmering Control for Domestic Induction Cookers," IEEE Transactions on Industry Applications, vol. 47, no. 5, pp. 2257-2267, September/October 2011.

[76] O. Jiménez, O. Lucía, L. A. Barragán, D. Navarro, J. I. Artigas, and I. Urriza, "FPGA-based test-bench for resonant inverter load characterization," IEEE Transactions on Industrial Informatics, vol. x, no. x, p. x, x 2013.

[77] V. M. Primiani, S. Kovyryalov, and G. Cerri, "Rigorous electromagnetic model of an induction cooking system," IET Science, Measurement \& Technology, vol. 6, no. 4, pp. 238-246, 2012.

[78] O. Jiménez, O. Lucia, I. Uriza, L. A. Barragán, P. Mattavelli, and D. Boroyevich, "FPGA-based gain-scheduled controller for resonant converters applied to induction cooktops," IEEE Transactions on Power Electronics, no. 2013.

[79] J. Acero, R. Alonso, L. A. Barragán, and J. M. Burdío, "Modeling of planar spiral inductors between two multilayer media for induction heating applications," IEEE Transactions on Magnetics, vol. 42, no. 11, pp. 3719-3729, November 2006.

[80] J. Acero, R. Alonso, J. M. Burdío, L. A. Barragán, and D. Puyal, "Analytical equivalent impedance for a planar circular induction heating system," IEEE Transactions on Magnetics, vol. 42, no. 1, pp. 84-86, January 2006.

[81] J. Acero, P. J. Hernández, J. M. Burdío, R. Alonso, and L. A. Barragán, "Simple resistance calculation in litz wire planar windings for induction cooking appliances," IEEE Transactions on Magnetics, vol. 41, no. 4, pp. 1280-1288, April 2005.

[82] C. Carretero, O. Lucía, J. Acero, and J. M. Burdío, "Computational modeling of two partly-coupled coils supplied by a double half-bridge resonant inverter for induction heating appliances," IEEE Transactions on Industrial Electronics, vol. 60, no. 8, pp. 3092-3105, August 2013.

[83] J. Acero, C. Carretero, R. Alonso, O. Lucía, and J. M. Burdío, "Mutual impedance of small ring-type coils for multi-winding induction heating appliances," IEEE Transactions on Power Electronics, vol. 28, no. 2, pp. 1025-1035, February 2013.

[84] J. Acero, C. Carretero, I. Millán, O. Lucía, R. Alonso, and J. M. Burdío, "Analysis and modeling of planar concentric windings forming adaptable-diameter burners for induction heating appliances," IEEE Transactions on Power Electronics, vol. 26, no. 5, pp. 1546-1558, May 2011

[85] C. Carretero, O. Lucía, J. Acero, R. Alonso, and J. M. Burdío, "Frequencydependent modeling of domestic induction heating systems using numerical methods for accurate time-domain simulation," IET Power Electronics, vol. 5, no. 8, pp. 1291-1297, September 2012. 
[86] J. Acero, R. Alonso, L. A. Barragán, and J. M. Burdío, "Magnetic vector potential based model for eddy-current loss calculation in round-wire planar windings," IEEE Transactions on Magnetics, vol. 42, no. 9, pp. 2152-2158, 2006.

[87] R. P. Wojda and M. K. Kazimierczuk, "Winding resistance of litz-wire and multistrand inductors," IET Power Electronics, vol. 5, no. 2, pp. 257-268, 2012.

[88] R. P. Wojda and M. K. Kazimierczuk, "Analytical optimization of solid-roundwire Windings," IEEE Transactions on Industrial Electronics, vol. 60, no. 3, pp. 1033-1041, 2013

[89] M. Bartoli, N. Noferi, A. Reatti, and M. K. Kazimierczuk, "Modeling Litz-wire winding losses in high-frequency power inductors," in IEEE Power Electronics Specialists Conference, 1996, pp. 1690-1696 vol.2.

[90] G. T. Landi and A. F. Bakuzis, "On the energy conversion efficiency in magnetic hyperthermia applications: A new perspective to analyze the departure from the linear regime," Journal of Applied Physics, vol. 111, no. 8, pp. 083915-0839158, August 2012.

[91] C.-C. Tai and M.-K. Chen, "A compact half-bridge heating system for magnetic nanoparticle thermotherapy applications," Biomedical Engineering. Applications, Basis and Communications, vol. 19, no. 01, pp. 27-35, 2007.

[92] C.-C. Tai and M.-K. Chen, "The design of a half-bridge series-resonant type heating system for magnetic nanoparticle thermotherapy," PIERS Online, vol. 4 no. 2, pp. 276-280, 2007.

[93] C. Gomez-Polo, S. Larumbe, J. I. Perez-Landazabal, and J. M. Pastor, "Analysis of heating effects (magnetic hyperthermia) in $\mathrm{FeCrSiBCuNb}$ amorphous and nanocrystalline wires," Journal of Applied Physics, vol. 111, no. 7, pp. 07A31407A314-3, 2012.

[94] M. E. Cano, A. Barrera, J. C. Estrada, A. Hernandez, and T. Cordova, "An induction heater device for studies of magnetic hyperthermia and specific absorption ratio measurements," Review of Scientific Instruments, vol. 82, no. 11, pp. 114904-114904-6, 2011.

[95] A. Candeo and F. Dughiero, "Numerical FEM models for the planning of magnetic induction hyperthermia treatments with nanoparticles," IEEE Transactions on Magnetics, vol. 45, no. 3, pp. 1658-1661, March 2009.

[96] P. Di Barba, F. Dughiero, and E. Sieni, "Synthesizing distributions of magnetic nanoparticles for clinical hyperthermia," IEEE Transactions on Magnetics, vol. 48, no. 2, pp. 263-266, February 2012.

[97] P. Di Barba, F. Dughiero, E. Sieni, and A. Candeo, "Coupled field synthesis in magnetic fluid hyperthermia," IEEE Transactions on Magnetics, vol. 47, no. 5, pp. 914-917, May 2011.

[98] P. R. Stauffer, P. K. Sneed, H. Hashemi, and T. L. Phillips, "Practical induction heating coil designs for clinical hyperthermia with ferromagnetic implants," IEEE Transactions on Biomedical Engineering, vol. 41, no. 1, pp. 17-28, January 1994.

[99] P. Di Barba, F. Dughiero, and E. Sieni, "Magnetic field synthesis in the design of inductors for magnetic fluid hyperthermia," IEEE Transactions on Magnetics, vol. 46 , no. 8, pp. 2931-2934, 2010.

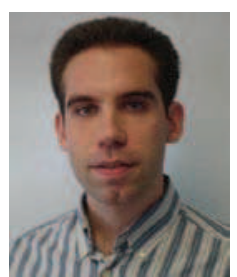

Oscar Lucia (S'04, M' 11) received the M.Sc. and Ph.D. degrees in Electrical Engineering from the University of Zaragoza, Spain, in 2006 and 2010, respectively.

He has been with the Department of Electronic Engineering and Communications at the University of Zaragoza, Spain, where he is currently an Assistant Professor. His main research interests include multiple output converters, digital control, and resonant power conversion for induction heating applications.

Dr. Lucía is a member of the Aragon Institute for Engineering Research (I3A).

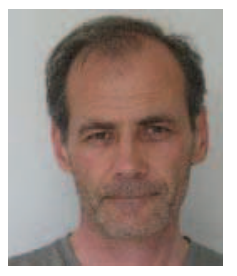

Pascal Maussion (M'07) got his MSc and $\mathrm{PhD}$ in Electrical Engineering in 1985 and 1990 from Toulouse Institut National Polytechnique (France). $\mathrm{He}$ is currently full Professor at the University of Toulouse and with LAPLACE, Laboratory for PLAsma and Conversion of Energy. His research activities deal with control and diagnosis of electrical systems (power converters, drives, lighting) and with the design of experiments for optimization in control and diagnosis. He is currently Head of Control and Diagnosis group in LAPLACE. He teaches control and diagnosis in a school of engineers.

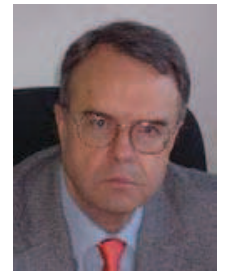

Enrique J. Dede (M'95) obtained his $\mathrm{PhD}$ in Electronics from the University of Valencia. Full Professor in Power Electronics at the University of Valencia since 1991 and R\&D Director at the company GH Electrotermia S.A.

Dr. Dede holds several international patents on high frequency inverters for induction heating and has written more than 200 papers in the field of Power Electronics. He has more than 30 years experience in the field of Power Electronics and particularly in the design of high frequency inverters for induction heating, telecom power and recently in the conception and design fast chargers for EV's.

Prof. Dede was former member of the European Working Group of the IASIEEE, nowadays he is member of the International Advisory Board of the PCIM-Europe and PCIM-Asia. Past President of the joint Spanish IEEE Chapter of the Power Electronics Society (PELS) and Industrial Electronics Society (IES).

Dr. Dede is also serving as the Vice- President of the European Power Electronics Association (EPE) and was the General Chair of the European Power Electronics Conference-EPE 2009, held in Barcelona (Spain).

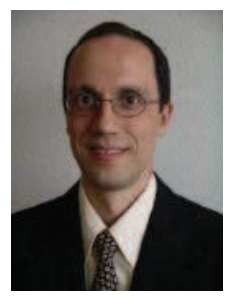

José M. Burdío (M'97 SM'12) received the M.Sc. and $\mathrm{Ph} . \mathrm{D}$. degrees in Electrical Engineering from the University of Zaragoza, Spain in 1991 and 1995, respectively.

$\mathrm{He}$ has been with the Department of Electronic Engineering and Communications at the University of Zaragoza, Spain, where he is currently a Professor. His main research interests include modeling of switching converters and resonant power conversion for induction heating applications.

Dr. Burdío is a member of the Aragon Institute for Engineering Research (I3A) 